\title{
MODEL KURIKULUM INTEGRATIF PESANTREN MAHASISWA DAN UIN MALIKI MALANG
}

\section{Husniyatus Salamah Zainiyati}

(Fakultas Tarbiyah dan Keguruan UIN Sunan Ampel Surabaya, email: husniyatus@yahoo.com)

Abstract: Some PTAINs develop a Ma'bad in their campuss. This article is aimed at analyzing the integration of curiculum of UIN Maliki into those of its Ma'had which is called correlated curriculum model. Following this model, students of the Ma'had have to take several steps to complete their study. They have to obtain a certificate of completion of ta'lim alafkar al-Islāmī and ta'lim al-Qur'ān which is required for enrolling in the Islamic studies program and taking comprehensive exam. The Ma'bad applies Qur'anic-based learning system. This system maps the concept of science and the religious knowledge, integrates the concept of science and theose of the religious knowledge and elaborates the Qur'anic verses scientifically. The ma'had maintains the tradition of congregational pray, recitation and memorization of the Qur'an and promotes infaq and șadaqah. All these are to develop the Islamic culture among the academic community at UIN Malang.

Abstrak: Beberapa PTAIN mengembangkan pesantren mahasiswa (Ma'had). Artikel ini mengkaji tentang model pengembangan kurikulum pesantren mahasiswa UIN Maliki Malang. Penulis menemukan babwa Kurikulum UIN Maliki Malang mengintegrasikan program Ma'had dengan kurikulum UIN Maliki Malang, sertifikat kelulusan ta'līm alafkar al-Islāmī dan ta'lim al-Qur'ān sebagai prasarat untuke memprogram studi keislaman dan sebagai prasarat ujian komprehensif. Ma'bad itu menerapkan pembelajaran berparadigma Qur'ani dengan tiga langkah aplikatif, yaitu, (a) memetakan konsep keilmuan umum dan keilmuan agama; (b) memadukan konsep keilmuan umum dan keilmuan agama; (c) mengelaborasi ayat-ayat al-Qur'an yang relevan secara saintifik. Tradisi ma'bad seperti salat berjama'ah, khatmil qur'an dan hifụul qur'ān, berinfaq dan sedekah untuk membentuk karakter dan mengembangkan kultur Islami di kalangan civitas akademika.

Keywords: kurikulum integratif, pesantren mahasiswa, universitas Islam. 
PENGEMBANGAN perguruan tinggi Islam pada mulanya didorong oleh beberapa tujuan, yaitu: (1) untuk melaksanakan pengkajian dan pengembangan ilmu-ilmu agama Islam pada tingkat yang lebih tinggi secara sistematis dan terarah; (2) untuk melaksanakan pengembangan dan peningkatan dakwah Islamiyah, dan (3) untuk melakukan reproduksi dan kaderisasi ulama dan fungsionaris keagamaan, baik pada kalangan birokrasi negara maupun swasta, serta lembaga-lembaga sosial, dakwah, pendidikan dan lain sebagainya. ${ }^{1}$ Jika dilihat dari kacamata historis ini, pesantren merupakan suatu yang urgen untuk mewujudkan kaderisasi ulama di perguruan tinggi Islam.

Malik Fajar menggambarkan adanya perbedaan antara tradisi pendidikan di pesantren dan perguruan tinggi, ia mengatakan bahwa pesantren mempunyai keunggulan dari segi moralitas tetapi minus tradisi rasionalitas, meskipun mampu melahirkan pribadi yang tangguh secara moral, tetapi lemah secara intelektual. Sebaliknya, perguruan tinggi mempunyai keunggulan dari sisi rasionalitas dan ditambah pengayaan di bidang skill, tetapi minus pengayaan moral. Dalam kenyataannya pendidikan tinggi hanya menghasilkan manusia yang cerdas tetapi kurang mempunyai kepekaan etika dan moral. ${ }^{2}$

Menurut Imam Suprayogo, perguruan tinggi dan pesantren sebe narnya memiliki akar budaya yang sama, yaitu sebagai lembaga pendidikan, hanya berbeda dalam lingkungannya. Jika perguruan tinggi dan pesantren dapat diintegrasikan dalam konteks yang integral, maka model atau sistem pendidikannya akan menjadi alternatif pengembangan pendidikan tinggi di Indonesia. ${ }^{3}$ Kemudian muncul pertanyaan, nilai-nilai apa saja yang dapat diambil dari pesantren, kemudian dibumikan dalam tradisi pendidikan di pergurauan tinggi? Dalam hal ini, lembaga pesantren difungsikan untuk membangun tradisi yang kokoh. Tradisi yang dimaksudkan disini adalah kebiasaan dan adat

${ }^{1}$ Azyumardi Azra, Pendidikan Islam Tradisi dan Modernisasi Menuju Melinium Baru (Jakarta: Logos Wacana Ilmu, 1999), 170.

${ }^{2}$ Ahmad Barizi (ed.), Holistik Pemikiran Pendidikan A. Malik Fadjar (Jakarta: RajaGrafindo Persada, 2005), 219-20.

IImam Suprayogo, Hubungan antara Perguruan Tinggi dan Pesantren (Malang: UIN Press, 2011), 45. 
istiadat yang bernuansa Islam. Misalnya, kebiasaan melakukan shalat berjama'ah, tadarrus al-Qur'an, shalat malam, disiplin, menghormati sesama kolega, menghargai ilmu.

Afandi Muchtar menyatakan, ke depan yang diharapkan bisa menyelesaikan relasi pendidikan, keislaman dan keindonesiaan adalah insitusi yang memiliki seperangkat pengetahuan yang cukup untuk hal ini. Problem ini tidak bisa diselesaikan secara parsial, namun harus dilakukan melalui sistem integratif. Melalui UIN maka pemecahan sistemik integratif akan bisa dilaksanakan.

Kebutuhan untuk mengembangkan kurikulum integratif pada pendidikan tinggi Islam disebabkan oleh adanya tuntutan kebutuhan masyarakat dan perkembanan IPTEK. Sumardi menyatakan dalam suasana yang semakin kompetetif khususnya di bidang ilmu pengetahuan dan kemampuan-kemampuan intelektual lainnya, para sarjana IAIN adalah yang banyak menderita kekurangan. Karena pada umumnya pendekatan kurikuler di IAIN masih sangat doktriner dan dogmatis dan sarjana Agama itu belum banyak "ber-try-out" dalam berbagai kesempatan. Sedangkan Ma'arif mengungkapkan bahwa kaitan antara pendidikan Islam dan konsep Ilmu, setidak-tidaknya ada tiga persolan pokok yang saling berkaitan yang dapat dijabarkan menjadi; 1) sosok muslim yang menjadi luntang-lantung bila dihadapkan kepada persoalan-persoalan dunia yang selalu berubah tampaknya disebabkan oleh idapan krisis identitas diri, sedangkan sistem pendidikan dan kurikulum pendidikan Islam yang sedang berlalu tidak dapat menolong keadaan, 2) kegiatan pendidikan Islam haruslah berorientasi ke arah transendental agar kegiatan itu punya makna spiritual yang mengatasi ruang dan waktu, dan 3) perlunya dilakukan redefinisi ulama. ${ }^{4}$

Untuk mengatasi berbagai kelemahan tersebut, maka Direktur Pendidikan Tinggi Islam (Diktis) mengambil kebijakan tentang pengembangan kurikulum PTAI, yaitu: 1) kurikulum berbasis hasil belajar; 2) kurikulum terdiri atas kurikulum inti dan kurikulum institusional; 3) kurikulum inti (40\%) ditetapkan oleh pemerintah dan berlaku secara nasional, sedangkan kurikulum institusional $(60 \%)$ ditetapkan oleh PTAI dan berlaku hanya di

${ }^{4}$ A Syafi'I Ma'arif, Peta Bumi Intelektualisme Islam di Indonesia (Bandung: Mizan, 1993), 12. 
PTAI tersebut; 4) kurikulum secara keseluruhan (inti dan institusional) ditetapkan oleh PTAI; dan 5) kualitas kurikulum menjadi tanggugjawab PTAI. ${ }^{5}$

Kebijakan tersebut mengandung makna bahwa: 1) kurikulum perlu dikembangkan dengan lebih menitikberatkan pada pencapaian target kompetensi daripada penguasaaan materi; 2) lebih mengakomodasikan keragaman kebutuhan dan sumberdaya pendidikan yang tersedia; 3) memberikan kebebasan yang lebih luas kepada pelaksana pendidikan di PTAI untuk mengembangkan dan melaksanakan program pendidikan sesuai dengan kebutuhan; 4) menggunakan prinsip kesatuan dalam kebijakan dan keragaman dalam pelaksanaan. Hamalik menyatakan bahwa kebijakan yang bertujuan untuk meningkatkan angka partisipasi masyarakat dan mutu pendidikan menuntut adanya pengembangan kurikulum, sedangkan pengembangan kurikulum yang bertujuan untuk meningkatkan relevansi program pendidikan dapat dicapai melalui pengembangan kurikulum daerah dan sekolah/perguruan tinggi serta melibatkan peran serta stakeholder. ${ }^{6}$

Berdasarkan studi pendahuluan diketahui bahwa UIN Maliki Malang merupakan salah satu PTAI yang menggunakan sistem penyelenggaraan pendidikan tinggi integratif yaitu sistem pendidikan dan tradisi di Ma'had Sunan Ampel Al-Aly diintegrasikan ke dalam sistem pendidikan di UIN Maliki Malang. ${ }^{7}$ Menteri Agama RI, -pada saat itu- Maftuh Basyuni juga mengacungi jempol terhadap UIN Malang. Ia mengatakan akan menerapkan program ke-ma'had-an seperti yang ada di UIN Malang pada seluruh Perguruan Tinggi Islam di Indonesia, sebagai pendukung pembelajaran mahasiswa yang berlatar belakang Islam. $^{8}$ Implikasi dari sistem pendidikan tinggi

${ }^{5}$ A. Furchan, dkk. Pengembangan Kurikulum Berbasis Kompetensi di PTAI (Yogyakarta: Pustaka Pelajar, 2005), 33.

'Oemar Hamalik, Manajemen Pengembangan Kurikulum (Bandung: Rosdakarya, 2006), 4.

7Pedoman Pendidikan Universitas Islam Negeri (UIN) Malang Tahun Akademik 2006/2007, 144-5.

${ }^{8}$ Tahap I pembangunan ma'had akan dilakukan pada 5 kota yaitu di UIN Jakarta, UINYogyakarta, IAIN Surabaya, Makasar dan Medan. GEMA 
integratif tersebut, semua mahasiswa UIN Maliki Malang baik dari prodi umum maupun prodi agama pada tahun pertama diwajibkan bertempat tinggal di ma'had UIN Maliki Malang dan mengikuti perkuliahan khusus program bahasa Arab (PKPBA) setiap hari pada pukul 14.00-20.00 WIB.

Tulisan ini akan membahas tentang bagaimana model kurikulum integratif pesantren mahasiswa dan UIN Maliki Malang. Penelitian ini menggunakan pendekatan deskriptif kualitatif. Pengumpulan data dihimpun dari observasi, wawancara dan dokumentasi. Data akan dianalisis melalui reduksi data, display data dan verifikasi/kesimpulan.

\section{Model Kurikulum Integratif Ma'had Sunan Ampel Al-Aly dan UIN Maliki Malang}

UIN Maliki Malang memanifestasikan konsep Ulul Albab dalam bentuk program pendidikan. Saefuddin menjelaskan bahwa Ulul Albab adalah pemikir intelektual yang memiliki kejaman analisis terhadap gejala dan proses alamiah dengan metode ilmiah induktif dan deduktif, serta intelektual yang membangun kepribadiannya dengan dhikir dalam keadaan dan situasi apapun, sehingga mampu memanfaatkan gejala, proses, dan sarana alamiah ini untuk kemaslahatan dan kebahagiaan seluruh umat manusia. Ulul Albab adalah intelektual muslim yang tangguh, yang tidak hanya memiliki ketajaman analisis obyektif, tetapi juga subyektif. ${ }^{9}$ Tujuan pendidikan ulul albab, dengan demikian adalah menyiapkan peserta didik yang memiliki beberapa karakteristik tersebut.

Menurut UU No. 20/2003 tentang Sistem Pendidikan Nasional pasal 36 ayat (2), bahwa kurikulum pada semua jenjang dan jenis pendidikan dikembangkan dengan prinsip diversifikasi sesuai dengan satuan pendidikan, potensi daerah dan peserta didik. Dalam pasal 38 ayat (3) dijelaskan bahwa kurikulum pendidikan tinggi dikembangkan oleh perguruan tinggi yang

Media Informasi dan Kebijakan Kampus edisi 25 November- Desember 2006, 7 .

${ }^{9}$ A.M. Saefuddin, Desekularisasi Pemikiran: Landasan Islamisasi (Bandung: Mizan, 1998), 34. 
bersangkutan dengan mengacu pada standart nasional pendidikan untuk setiap program studi.

Berdasarkan UU tersebut, menjadikan konsep Ulul Albab sebagai asumsi dasar dalam pengembangan pendidikan di UIN Maliki Malang merupakan perwujudan dari prinsip diversifikasi, sehingga dapat dibenarkan selama tetap memperhatikan standard nasional pendidikan. Untuk mewujudkan tujuan pendidikan tersebut, diperlukan struktur keilmuan yang jelas.

\section{Struktur keilmuan integratif}

Struktur keilmuan UIN Maliki Malang dibangun berdasarkan prinsip universalitas ajaran Islam yang digambarkan sebagai pohon ilmu yang rindang dan kokoh. Gagasan Imam Suprayogo tentang "Pohon Ilmu" yang dijadikan sebagai blue print pengembangan ilmu di UIN Maliki Malang, memang ada sedikit perdebatan pada tataran epistemologinya. Menurut Muhaimin, sumber ilmu pengetahuan itu pada dasarnya datangnya dari Allah. Allah menciptakan alam semesta (ayat-ayat kawniyyah) dan al-Qur'an serta Hadis (ayat-ayat qawliyyah). Oleh karenanya kedua sumber tersebut saling menjelaskan atau konsultasi dan tidak bertentangan terhadap berbagai ilmu pengetahuan tentang hakekat kebenaran. Selama ini orang berfikir di sayap kanan dan kiri disebut dikotomik.

Dalam mengkaji ilmu Islam, menurut Fazlur Rahman dalam Hamdi ${ }^{10}$ sebaiknya harus dibedakan antara Islam sebagai objek kajian keilmuan dan Islam sebagai landasan etis. Sebagai objek kajian keilmuan Islam harus tunduk dan patuh terhadap prosedur-prosedur keilmuan. Sebagai contoh, al-Qur'an sebagai teks, maka ia bisa dikaji oleh siapa saja, tidak peduli apakah orang itu mempercayai al-Qur'an sebagai wahyu yang datang dari Tuhan atau tidak. Inilah yang dikatakan Fazlur Rahman bahwa orang non-Muslim pun bisa mengkaji al-Qur'an dan hasilnya memiliki derajat yang sama dengan tafsir yang disusun oleh seorang Muslim. Kedua tafsir tersebut sama-sama memiliki

${ }^{10}$ Zainul Hamdi, “ Menilai Ulang Gagasan Integrasi Ilmu Pengetahuan sebagai Blue Print Pengembangan Keilmuan UIN”, dalam Zainal Abidin Bagir, dkk (editor), Integrasi Ilmu dan Agama: Interpretasi dan Aksi (Yogyakarta: MYIA-CRCS dan Suka Press, 2005), 183-5. 
derajat relatif dalam perspektif ilmu. Oleh sebab itu, al-Qur'an sebagai teks harus terbuka untuk dikaji melalui teori-teori teks sebagaimana teori-teori tersebut digunakan untuk mengkaji teksteks sekuler non-ilahi. Di sisi lain, Islam sebagai landasan etis, ia menjadi pedoman pemeluknya untuk bertindak arif dalam hidup, seperti sikap amanah, adil, tasāmuh, tawāsut, tawāzun dan lain sebagainya. Hal ini pun dalam operasionalisasinya harus tunduk pada ruang dan waktu yang melingkupinya. Akan tetapi, bila Islam dipandang sebagai landasan etis, seharusnya dalam proses pembelajaran pendidikan agama bukan hanya dijadikan sebagai "pelajaran atau pengetahuan" tentang ilmu agama, tetapi seharusnya dilakukan dengan cara penanaman nilai-nilai luhur dan bentuk keteladanan dan pengalaman akan lebih efektif daripada internalisasi nilai melalui ucapan dan ceramah seperti yang selama ini terjadi di perguruan tinggi Islam.

Dalam kasus Islam sebagai objek kajian keilmuan, hasil penelitian Hamdi11 menunjukkan bahwa rumpun ilmu-ilmu keislaman hanyalah menjadi bagian kecil dari kegiatan keilmuan secara umum di perguruan tinggi Islam (PTI). Ilmu-ilmu yang dikaji di fakultas agama, misalnya jurusan syariah dan tarbiyah adalah bagian kecil dari anggota ilmu-ilmu non-eksakta pada Perguruan Tinggi Islam (PTI). Menyadari hal ini terdapat konsekuensi, bahwa kalau selama ini animo masyarakat untuk melanjutkan studi ke PTI relatif kecil dibanding dengan ke Perguruan Tinggi Umum (PTU), hal ini tidak semata-mata mutu PTI lebih jelek dibanding PTU, akan tetapi karena mereka tidak ingin menjadi ahli agama yang sebenarnya dalam PTI juga terdapat fakultas-fakultas umum. Image inilah yang sampai sekarang masih melekat pada pola pikir masyarakat, sehingga PTI harus bekerja keras meyakinkan pada masyarakat bahwa PTI ikut andil dalam mempersiapkan lulusan calon teknolog, birokrat, politisi dan lain sebagianya, bukan semata-mata ahli agama.

Eksistensi sebagian PTI, dengan simbol "Islam"nya kemudian muncul adanya kegamangan. Kegamangan itu bertumpu pada hasrat agar ilmu-ilmu yang terlanjur dicap sekuler tersebut mendapatkan identitas Islam dalam proses

${ }^{11}$ Ibid., 186. 
pembelajaran. Di titik inilah kemudian semangat Integrasi ilmu dan agama menemukan momentumnya. Maka, mulai muncul psikologi Islam, ekonomi Islam, sains Islam dan seterusnya. Kemudian, disusunlah struktur keilmuan dengan meletakkan alQur'an dan Hadis sebagai sumbernya. Arahnya jelas, struktur keilmuan ini digunakan untuk mengidentifikasi ilmu Islami dan ilmu non-Islami.

Menurut Imam Suprayogo dalam Hamdi ada dua tawaran terkait dengan peletakan al-Qur'an sebagai sumber ilmu pengetahuan. Pertama, meletakkan al-Qur'an sebagai konsep dasar atau inspirasi yang kemudian dikembangan melalui berbagai riset ilmiah (lihat gambar 1). Kedua, meletakkan alQur'an (fenomena naqliyyah) dan alam (fenomena kawniyyah) menjadi dua sumber yang setara bagi bangunan ilmu pengetahuan (lihat gambar 2). ${ }^{12}$

Gambar 1. Struktur Keilmuan Dikotomik

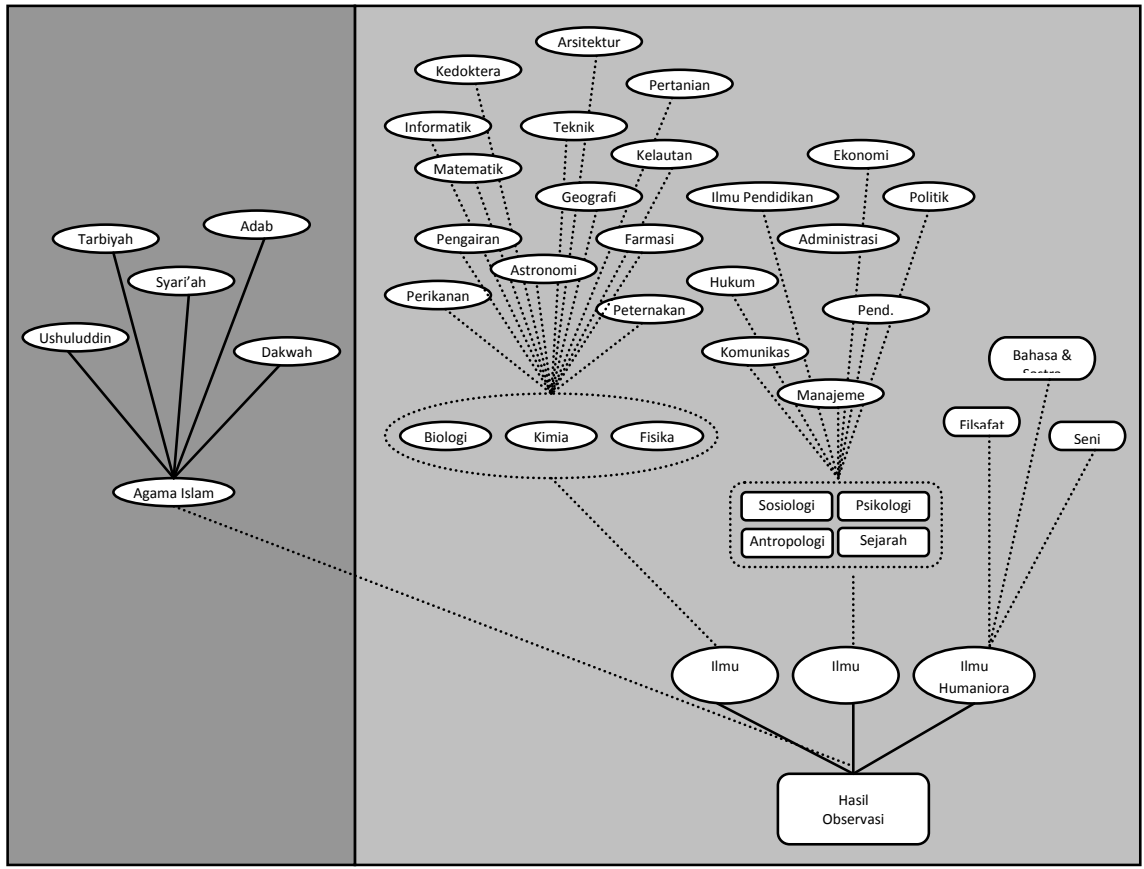

${ }^{12} I b i d, 189$. 


\section{Gambar 2. Bangunan Keilmuan Integratif}

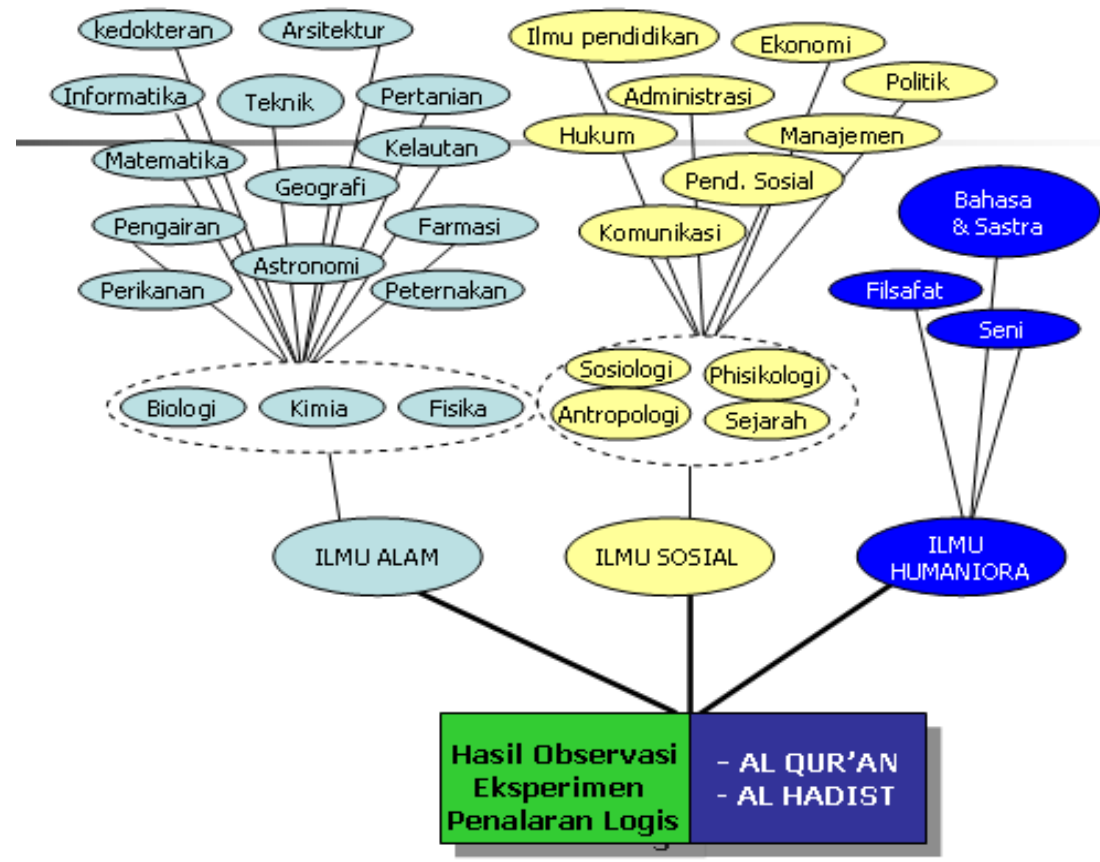

Pada gambar satu mucul sebuah pertanyaan, apa yang dimaksud dengan al-Qur'an sebagai sumber ilmu pengetahun? Kalau yang dimaksud adalah al-Qur'an sebagai salah satu makhluk Tuhan yang dapat dijadikan sebagai salah satu sumber ilmu pengetahuan maka dapat dibenarkan, karena Allah juga menciptakan fenomena lain yang bersifat kawniyyah (alam semesta) dan fenomena nafsiyah (manusia) yang juga memiliki kontribusi besar sebagai sumber ilmu pengetahuan, teknologi dan seni.

Bagaimana bila al-Qur'an dijadikan sebagai sumber inspirasi, pertanyaan berikutnya adalah apakah seorang ilmuwan yang menggagas teori dari inspirasi yang melalui renungan tentang fenomena di sekitarnya tidak atau kurang Islami teorinya dari teori seorang ilmuwan yang mendapat inspirasi langsung dari alQur'an? Kalau dikatakan “ya”, pertanyaan berikutnya adalah dengan ukuran apa sebuah teori dikatakan Islami dan tidak Islami? Apakah sebuah teori Islami semata-mata didasarkan atas sumber inspirasinya ataukah kejujuran ilmiah yang diemban oleh seorang ilmuwan sekalipun dia tidak memperoleh inspirasinya 
dari al-Qur'an, atau bahkan mungkin dia tidak bisa membaca alQur'an? Kalau di dalam salah satu ayat al-Qur'an ditemukan istilah dharrah yang selama ini dijadikan pembenar atas teori atom, maka pertanyaannya adalah apakah itu bersifat justifikatif ataukah inspiratif, jika faktanya bahwa Niels Bohr menemukan atom tidak terinspirasi oleh ayat al-Qur'an. Jika faktanya hanyalah justifikatif, seringkali aplikasi praktis Islamization of knowledge adalah upaya mencari ayat atau Hadis untuk menjustifikasi pengetahuan tertentu yang dianggap Islami, maka gugurlah klaim al-Qur'an sebagai sumber inspirasi ilmu pengetahuan. Kalau kemudian dikatakan bahwa ilmu pengetahuan dibangun dari proses riset ilmiah atas fakta empiris, apa makna statement al-Qur'an sebagai sumber ilmu pengetahuan tersebut?. Oleh sebab itu, ada sekian banyak problem epistemologis yang terkait dengan dua hal tersebut. Cara pandang yang berbeda akan menghasilkan rumusan pengetahuan yang berbeda, baik mengenai alam maupun alQur'an. ${ }^{13}$

Realitas keilmuan seperti ini semakin memperlihatkan bahwa aktivitas ilmiah adalah aktivitas ilmiah, dia tidak bisa disekat berdasarkan keyakinan-keyakinan religius apapun. Seorang ahli fisika secara keilmuan tidak harus bisa membaca al-Qur'an. Kalaupun bisa lebih baik sejauh rumusannya menggunakan prosedur keilmuan yang benar, bisa diterima, dan ini sama sekali tidak memiliki konsekuensi teologis Islam atau non-Islam. Sejauh ilmu-ilmu keislaman, seperti tafsir dipahami sebagai satu ilmu, maka keharusan bagi seseorang untuk mengerti ilmu nahwu, ilmu saraf, ilmu mantiq, ilmu balaghah, ilmu ma'ani ataupun bahasa Arab, dan berbagai perangkat rumpun ilmuilmu keislaman yang lain bukan sebagai keharusan teologis, tapi keharusan ilmiah, bahwa seseorang bisa mempelajari tafsir kalau dia memahami kaidah-kaidah bahasa Arab dan beberapa ilmu pendukungnya.

Jika kita menggagas suatu teori ilmiah yang dianggap berdasarkan al-Qur'an dan Hadis, maka itu hanyalah salah satu varian dari sekian banyak pandangan yang berbeda-beda. Sebuah ayat tidak bisa memberi priveles apapun terhadap teori kita atas

13Zainul Hamdi, "Menilai..., 186-8. 
teori lain yang tidak ada ayatnya. Bahkan menurut Hamdi ketika ada dua orang ilmuwan yang mendapatkan inspirasinya dari alQuran, bisa jadi dia akan mengkonstruksi teori yang berbeda. Hal ini karena inspirasi Qur'ani lahir bukan sebagai sesuatu yang given, tapi disebabkan oleh cara seseorang memandang dan membaca al-Quran. ${ }^{14}$

Ahmad Tafsir mengungkapkan bahwa ilmu adalah milik Allah, sehingga teori-teori yang didapat dari mempelajari alQur'an tidak mungkin berlawanan dengan teori-teori yang didapat dari mempelajari al-Kawn (alam semesta) sebab dua kelompok teori itu adalah teori dari Tuhan, karena tidak ada perlawanan dalam pengetahuan Tuhan. ${ }^{15}$

Berdasarkan pemikiran tersebut, bahwasannya konsep integrasi ilmu umum dan ilmu agama yang digunakan sebagai blue print pengembangan keilmuan UIN Malang sebenarnya sebagai upaya untuk menghilangkan dikotomi keilmuan tersebut. ${ }^{16}$ Meskipun para ilmuwan dahulu seperti Ibn Khaldun membagi ilmu menjadi dua yaitu ilmu naqliyyah dan ilmu 'aqliyyah. Imam Ghazali membuat klasifikasi ilmu menjadi ilmu-ilmu agama atau ukhrawi yang disebut fard 'ain dan ilmu-ilmu umum atau duniawi disebut fard kifayah. Kedua ilmu tersebut menurut al-Ghazali wajib ditempuh dan dimiliki oleh umat Islam. Menurut Azyumardi Azra klasifikasi ilmu tersebut bukan dimaksud mendikotomi ilmu antara satu dengan yang lain, tetapi hanya sekadar klasifikasi. Dalam konteks ini ilmu agama Islam merupakan salah satu saja dari berbagai cabang ilmu secara keseseluruhan. ${ }^{17}$

Dengan demikian, Islamic knowledges (al-'ulüm al-Islämiyyah) yang dikembangkan oleh UIN Maliki Malang adalah ilmu pengetahuan yang dibangun berdasarkan ajaran Islam yakni al-

${ }^{14}$ Ibid.

${ }^{15}$ Ahmad Tafsir, Filsafat Pendidikan Islami Integrasi Jasmani, Rohani dan Kalbu Memanusiakan Manusia (Bandung: Remaja Rosdakarya, 2010), 111.

${ }^{16}$ Mengenai konsep integrasi ilmu umum dan ilmu agama masingmasing UIN di Indonesia memiliki konsep keilmuan yang berbeda tetapi dengan tujuan yang sama.Misalnya UIN Syarif Hidayatullah Jakarta dengan konsep Integrasi Ilmu, UIN Sunan Kalijaga Yogyakarta dengan Jaring LabaLaba, UIN Bandug dengan konsep Wahyu Memandu Ilmu.

${ }^{17}$ Azra, Pendidikan ..., xii-xiv. 
Qur'an dan Hadis, sekaligus pengetahuan yang sama dibangun berdasarkan hasil observasi, eksperimentasi, dan penalaran logis. Jika al-Qur'an dan Hadis diletakkan pada posisi sumber ilmu, maka tidak akan terjadi cara pandang ilmu yang dikotomik dan justru merendahkan posisinya Kitab Suci. Sudah barang tentu sebagai konsekwensi al-Qur'an yang bersifat Universal masih diperlukan sumber pengetahuan lain yang bersifat teknis, yaitu ilmu pengetahuan yang diperoleh melalui observasi, eksperimen dan penalaran logis.

Paparan di atas menegaskan bahwa konsep integrasi keilmuan UIN Malang, menegasikan Islam sebagai paradigma dalam berbagai kajian ilmu pengetahuan. Melalui pemahaman seperti ini ayat-ayat qawliyyah yang berhubungan dengan ilmu pengetahuan meniscayakan untuk dielaborasi secara saintifik sesuai dengan kebutuhan kerja ilmiah yang dibangunnya. Seperti diungkapkan Oesman Bakar, al-Qur'an bukanlah kitab sains. Tetapi ia memberikan pengetahuan tentang prinsip-prinsip sains, yang selalu dikaitkannya dengan pengetahuan metafisik dan

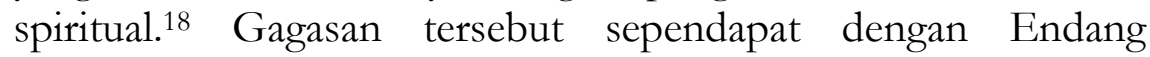
Saefuddin Anshari bahwa Al-Qu'an atau ayat Qur'aniyyah tidak lain adalah pembukuan segenap alam semesta atau ayat Kawniyyah dalam satu al-Kitab. Kedua ayat Allah yaitu ayat Qur'aniyyah dan ayat Kawniyyah itu saling menafsirkan. ${ }^{19}$ Dalam proses pengilmuan Islam Kuntowijoyo menawarkan dua metodologi, yaitu integralisasi dan objectivikasi. ${ }^{20}$

\section{Kurikulum integratif yang dikembangkan}

Untuk merealisasikan struktur keilmuan dengan metafora pohon ilmu, kurikulum UIN Maliki Malang diintegrasikan dengan program Ma'had Sunan Ampel Al-Aly. Berdasarkan struktur keilmuan tersebut, UIN Maliki Malang mewajibkan seluruh mahasiswa tanpa melihat jurusan atau program studi

18Oesman Bakar, Taubid dan Sains Perspektif Islam tentang Agama dan Sains, ter. Yuliani Liputo dan M. S. Nasrulloh (Bandung: Pustaka Hidayah, 2008), 151.

${ }^{19}$ Endang Saifuddin Anshari, Ilmu, Filsafat dan Agama (Surabaya: Bina Ilmu, 1987), 176.

${ }^{20}$ Kuntowijoyo, Islam sebagai Ilmu: Epistemologi, Metodologi dan Etika, (Yogyakarta: Tiara Wacana, 2007), 49. 
apa, untuk menguasai pondasi atau akar keilmuan lebih dahulu terdiri dari; 1) Bahasa Arab dan Inggris, 2) Filsafat, 3) Ilmu Kealaman, 4) Ilmu Sosial, dan 5) Pendidikan Pancasila dan Kewarganegaraan, sebelum mengkaji ajaran Islam (pada pohon ilmu digambarkan sebagai sebuah batang), meliputi: 1) al-Qur'an dan al-Sunnah, 2) Sirah Nabawiyah dan Sejarah Peradaban Islam, 3) Pemikiran Islam terdiri atas; Teologi, Fiqih, dan Tasawuf, 4) Pemahaman terhadap masyarakat Islam. Selanjutnya mengkaji keilmuan sesuai dengan pilihan dan jurusan serta Pendidikan Islam Tradisi dan program studi masing-masing (yang digambarkan sebagai sebuah dahan dan ranting).

Struktur kurikulum tersebut bila dikaitkan dengan realitas sejarah pengembangan perguruan tinggi Islam didorong oleh beberapa tujuan, yaitu: 1) untuk melaksanakan pengkajian dan pengembangan ilmu-ilmu agama Islam pada tingkat yang lebih tinggi secara lebih sistematis dan terarah; 2) untuk melaksanakan pengembangan dan peningkatan dakwah Islam; dan 3) untuk melakukan reproduksi dan kaderisasi ulama dan fungsionaris keagamaan, baik pada birokrasi negara maupun sektor swasta, serta lembaga-lembaga sosial, dakwah, pendidikan dan sebagainya. ${ }^{21}$ Maka pemahaman akan tujuan yang pertama berimplikasi pada tujuan kedua dan ketiga tersebut di atas.

Tujuan kedua adalah untuk melaksanakan pengembangan dan peningkatan dakwah Islam. Makna dakwah Islam bukan lagi tereduksi menjadi dakwah dalam arti mengkomunikasikan alulüm al-naqliyyah (perennial knowledge) saja, yang mencakup: studi al-Qur'an, studi Hadis, sirah nabawiyah, tauhid, ushūl fiqh dan fiqh, bahasa arab al- Qur'an, serta bidang-bidang studi tambahan yang meliputi: metafisika Islam, perbandingan agama, dan kebudayaan Islam. Tetapi menurut Bilgrami juga bagaimana alulüm al-naqliyyah (perennial knowledge) memberi spirit dan landasan, serta ancangan bagi pengembangan al-ulum al-aqliyyah (acquired knowledge), yang mencakup: 1) Arts (ilmu-ilmu imajinatif), seperti, kesenian dan arsitektur Islam, bahasa-bahasa, kesusasteraan; 2) ilmu-ilmu intelektual, yang meliputi: ilmu-ilmu sosial, filsafat, pendidikan, ekonomi, ilmu politik, sejarah, peradaban Islam, geografi, sosiologi, linguistik, psikologi,

${ }^{21}$ Azra, Pendidikan..., 170. 
antropologi; 3) ilmu-ilmu kealaman, yang meliputi: filsafat ilmu pengetahuan, matematika, statistika, fisika, kimia, biologi, astronomi, ilmu-ilmu angkasa luar dan sebagainya; 4) ilmu-ilmu terapan, yang meliputi teknik dan teknologi, kedokteran, pertanian dan kehutanan; 5) ilmu-ilmu praktis, meliputi: perdagangan, ilmu-ilmu administrasi, ilmu-ilmu perpustakaan, ilmu-ilmu ke rumah tanggaan, ilmu komunikasi dan sebagainya. 22

Sedangkan tujuan ketiga adalah untuk melakukan reproduksi dan kaderisasi ulama. Pemahaman tentang ulama bukan lagi terbatas pada mereka yang menguasai al-ulüm al-naqliyyah (perennial knowledge), tetapi juga mereka yang menguasai al-'ulüm al-aqliyyah (acquired knowledge), serta menjadikan al-ulum alnaqliyyah (perennial knowledge) sebagai landasan, spirit serta ancangan bagi pengembangan al-ulum al-aqliyyah (acquired knowledge) tersebut.

Dilihat dari sudut pandang tersebut, menurut Muhaimin ${ }^{23}$ studi keislaman akan mengalami pemekaran makna, yaitu: Pertama, studi Islam sebagai sumber ajaran yang merupakan wahyu Ilahi yang terhimpun dalam al-Qur'an dan al-Hadis. Dalam bidang yang pertama ini, studi Islam bertumpu pada studi kewahyuan yang diwujudkan dalam bentuk mata kuliah seperti studi al-Qur'an, studi Hadis dan lain-lainnya. Kedua, studi Islam sebagai bagian dari pemikiran atau bagian dari fiqh dalam arti luas. Dalam sejarah pemikiran Islam setidak-tidaknya ada lima bidang pemikiran Islam yang menonjol, yaitu: Akidah-teologi (ilmu kalam), hukum dalam arti luas (shari'ah), filsafat, Akhlaksufisme (tashawuf), ilmu pengetahuan teknologi seni (al-'ulüm aldunyāwiyyah), yang mencakup bidang-bidang yang mencakup luas mulai dari IPA, matematika hingga teknik arsitektur, informatika dan astronomi. Ketiga, studi Islam sebagaimana yang dialami, diamalkan dan diterapkan dalam kehidupan. Dengan bersumber pada al-Quran dan Hadis, kemudian dijabarkan dalam berbagai

${ }^{22}$ Hamid Hasan Bilgrami dan Sayid Ali Ashraf, Konsep Universitas Islam, ter. Machnun Husein (Yogyakarta; Tiara Wacana, 1999), 14-20.

${ }^{23}$ M. Zainuddin, dkk. (ed.), Memadu Sains dan Agama (Malang: UIN Press, 2009), xxvii-xxviii. 
pemikiran, ajaran Islam kemudian diamalkan dan diterapkan oleh umat Islam hingga membentuk peradaban Islam.

Kajian yang dikembangkan UIN Maliki Malang untuk penyiapan Ulul Albab tidak sekedar menekankan pada pengembangan ilmu-ilmu pengetahuan agama Islam dalam arti al-ulum al-naqliyyah (bersumber wahyu), tetapi sekaligus menyangkut kajian al-ulum al-aqliyyah (bersumber pada alam semesta) yang bersifat empiris, selaras dengan karakteristik Ulul Albab tersebut di atas. Karena itulah, pengembangan al-ulüm alnaqliyyah semata dianggap kurang relevan lagi dengan pengembangan ilmu pengetahuan dan tuntutan pembangunan nasional, karena bersifat sangat sektoral, hanya memenuhi satu sektor tertentu dalam kehidupan Islam di Indonesia, yaitu memenuhi kebutuhan sarjana-sarjana yang mendapatkan pengetahuan tinggi mengenai agama Islam. Dengan demikian konsep Ulul Albab yang diharapkan adalah mereka yang menguasai Iptek dan sekaligus hidup di dalam nilai-nilai agama Islam.

Berdasarkan buku Pedoman Pendidikan UIN Maliki Malang tahun 2012, Mata Kuliah Dasar Keuniversitasan yang harus ditempuh oleh semua mahasiswa UIN Maliki Malang, terdiri dari; a) Pendidikan Kewarganegaraan; b) Bahasa Indonesia; c) Bahasa Inggris; d) Ilmu Alamiah Dasar; e) Ilmu Budaya Dasar; f) Filsafat Ilmu; g) Studi al-Qur'an; h) Studi al-Hadis; i) Studi Fiqh; j) Akhlak/Tasawuf; k) Sejarah Peradaban Islam; l) Teologi Islam; m) Mahārat al-Istima' I, II; n) Mahārat al-Kalam I, II; o) Mahārat alQirāah I, II; p) Mahārat al-Kitābah I, II; q) Tarbiyah Ulul Albab. ${ }^{24}$

Untuk tercapainya pengembangan pada mata kuliah dasar keuniversitasan tersebut, maka menurut Muhaimin harus dibarengi dengan pembiasaan dan pembelajaran di ma'had. Oleh karena itulah, struktur kurikulum mata kuliah dasar keuniversitasan UIN Malang diintegrasikan dengan pembelajaran di Ma'had Sunan Ampel Al-Aly, dengan menjadikan sertifikat kelulusan ta' lim al-afkear al-Islami dan ta'lim al-Qur'an sebagai prasarat untuk memprogram studi keislaman, dan sebagai prasarat ujian komprehensif. Bagi mahasiswa yang belum lulus, maka mahasiswa tersebut dapat memprogram mata

${ }^{24}$ Pedoman Pendidikan UIN Maliki Malang, 2010, 35-6. 
kuliah studi keislaman dengan syarat tetap mengikuti program remidial ta'lim ma'had sampai yang bersangkutan dinyatakan lulus, dan nilai kelulusan program remidial tersebut menjadi syarat penerbitan nilai akhir untuk mata kuliah studi keislaman yang diprogram. ${ }^{25}$

Program sabāḥ al-lughah yang dilaksanakn di ma'had, PKPBA dan PKPBI dilaksanakan di UIN Maliki Malang untuk memperkuat kemampuan bahasa Arab dan Inggris mahasiswa, yang pada gilirannya dapat digunakan sebagai alat untuk mengkaji sumber ajaran Islam dan juga disiplin ilmu masingmasing. Seperti diungkapkan Karel A. Steenbrink bahwa penguasaan bahasa Arab juga penting di luar penguasaan Agama. ${ }^{26}$ Sedangkan pembinaan kajian al-Qur'an bagi dosen melalui kegiatan di LKQS, pembinaan membaca al-Qur'an bagi karyawan melalui kegiatan tahsin al-Qur'an di HTQ.

Pembelajaran di Ma'had Sunan Ampel Al-Aly adalah bagian integral dari sistem kelembagaan dan pendidikan UIN Maliki Malang. Karena itulah, pembelajaran di ma'had diatur oleh Pembantu Rektor Bidang Akademik melalui mudir dan pengurus ma'had, baik menyangkut kurikulum, perkuliahan, dan sistem evaluasi. Hal ini untuk mengukur tingkat keberhasilan pembelajaran ta'lim al-afkear al-Islämi dan ta'Tim al-Qur'än.

Sedangkan metode pembelajaran di Ma'had Sunan Ampel Al-Aly memadukan antara metode dialog dan metode bandongan, misalnya pada pembelajaran Ta'Tim al-Afkar al-Islämiyah kelas takhassus, bagi mahasiswa yang mampu membaca kitab kuning dengan lancar langsung dibimbing oleh Kyai ma'had dengan sistem dialog. Sementara bagi mahasiswa yang belum mampu membaca kitab kuning dengan lancar menggunakan sistem bandongan dan dipandu oleh seorang mushrif sampai dia mampu membaca kitab kuning dengan lancar. Pada pembelajaran Ta'lim al-Qur'an kelas tarjamah dan tafsir, pada kelas ini bagi mahasiswa yang memiliki kemampuan membaca dan mengkaji al-Qur'an dengan baik akan dibimbing langsung oleh pengasuh masingmasing unit. Sedangkan bagi mahasiswa yang memiliki

${ }^{25}$ Ibid., 53.

${ }^{26}$ Karel A. Steenbrink, Pesantren Madrasab Sekolah Pendidikan Islam dalam Kurun Modern (Jakarta: LP3ES, 1986), 176. 
pemahaman yang kurang terhadap al-Qur'an di masukkan pada kelas taswit dan dibimbing oleh mushrif dan murabbi.

Langkah-langkah yang dapat digunakan untuk menerapkan pembelajaran berparadigma Qur'ani yaitu, (a) memetakan konsep keilmuan umum dan keilmuan agama; (b) memadukan konsep keilmuan umum dan keilmuan agama; (c) mengelaborasi ayat-ayat al-Qur'an yang relevan secara saintifik.

Mencermati struktur kurikulum tersebut di atas, maka model pengorganisasian kurikulum yang dipakai UIN Maliki Malang adalah correlated curriculum. Dalam hal ini, misalnya, mata kuliah studi keislaman dihubungkan dengan pembelajaran ta'lim al-afkear al-Islämi dan ta'tim al-Qur'än di ma'had. Program PKPBA dan PKPBI di universitas dikaitkan dengan program sabăh al-lughah. Di samping itu program ma'had seperti peningkatan kompetensi ketrampilan, peningkatan kualitas dan kuantitas Ibadah, dan pengabdian masyarakat juga dikaitkan dengan pembelajaran di UIN Maliki Malang.

Sebagaimana diungkapkan oleh Hasyim bahwa pesantren dapat dijadikan sebagai sistem pendidikan alternatif yaitu, pertama, apabila pesantren tidak menolak perkembangan paradigma, sains dan teknologi modern, dengan tanpa meninggalkan nilai-nilai paradigma keislaman. Kedua, harus ada sebuah kurikulum yang seimbang antara trilogi keilmuan yang berlandaskan Islam, 1) Islamic natural sciences, 2)Islamic social sciences, 3)religion sciences. Diharapkan dengan kurikulum ini, santri dapat menggabungkan antara pengetahuan, ketrampilan dan sikap. ${ }^{27}$

Kajian terhadap kurikulum UIN Maliki Malang antara lain berupaya memberikan basic competencies ilmu-ilmu keislaman sebagai ciri khas UIN, sekaligus sebagai landasan bagi pengembangan bidang-bidang studi yang dikembangkan pada jurusan yang ada, maka program kajian ta'tim al-afkēr al-Islämiyah dan ta'tim al-Qur'an sebaiknya tidak hanya membahas materi seperti fiqh, tasawuf, aqidah, tetapi kajian ta'trm al-afkēr alIslamiyah dan ta'lim al-Qur'ān dapat dikembangkan dengan

${ }^{27}$ M. Affan Hasyim, "Menatap Masa Depan Pesantren dalam Menyongsong Indonesia Baru", dalam A.Z. Fanani dkk., (ed.), Menggagas Pesantren Masa Depan Geliat Suara Santri Untuk Indonesia Baru (Yogyakarta: Qirtas, 2003), 231. 
mengambil materi Qur'an dan Hadis yang berhubungan dengan perkembangan sains dan teknologi. Sehingga basic keislaman tersebut dapat digunakan mahasiswa atau dosen untuk mengembangkan bidang kajian sesuai dengan jurusannya masing-masing. Dengan demikian, ta'tim al-afkēr al-Islämiyah dan ta'Tim al-Qur'an tidak hanya sebagai prasyarat memprogram mata kuliah keislaman di UIN, akan tetapi bisa digunakan sebagai penunjang mata kuliah lainnya.

Dengan demikian, implementasi kurikulum integratif di UIN Maliki Malang menurut peneliti, menggunakan pendekatan kebutuhan sosial (social demand approach) yang diajukan Gorton. Dengan alasan dalam rangka mewujudkan visi dan misi UIN Maliki Malang dengan empat pilar yaitu (1) Kedalaman Spiritual; (2) Keluhuran Akhlak; (3) Keluasan Ilmu Pengetahuan; dan (4) Kematangan Profesional, maka model pembelajaran di UIN Maliki Malang adalah dengan mengintegrasikan kurikulum ma'had dengan kurikulum UIN. Di samping itu, Muhaimin juga menambahkan bahwa, pengembangan kurikulum di UIN Malang menggunakan empat pendekatan dengan mempertimbangkan karakteristik tujuan dan isi kurikulumnya, yaitu: 1) pendekatan subyek akademik, 2) pendekatan humanistik, 3) pendekatan teknologik, 4) pendekatan rekonstruksi sosial.

\section{Catatan Akhir}

Struktur keilmuan UIN Maliki Malang dengan metafora pohon ilmu bersifat dialogis-konsultatif. Adapun kurikulum UIN Maliki Malang mengintegrasikan program Ma'had Sunan Ampel Al-Aly dengan kurikulum UIN Maliki Malang, dengan menjadikan sertifikat kelulusan ta'lim al-afkar al-Islämi dan ta'Iim al-Qur'an sebagai prasarat untuk memprogram studi keislaman dan sebagai prasarat ujian komprehensif. Pembinaan kajian alQur'an bagi dosen melalui kegiatan di LKQS dan pembinaan membaca al-Qur'an bagi karyawan melalui kegiatan tahsin alQur'an dan pembinaan hafalan al-Qur'an mahasiswa di HTQ. Langkah-langkah yang dapat digunakan untuk menerapkan pembelajaran berparadigma Qur'ani yaitu, (a) memetakan konsep keilmuan umum dan keilmuan agama; (b) memadukan 
konsep keilmuan umum dan keilmuan agama; (c) mengelaborasi ayat-ayat al-Qur'an yang relevan secara saintifik. Tradisi ma'had seperti salat berjama'ah, dhikir bersama, khatmil qur'an dan bif:̧ul qur'an, puasa senin dan kamis, berinfaq dan shadaqah untuk membentuk karakter mahasiswa dan mengembangkan kultur Islami di kalangan civitas akademika UIN Maliki Malang. Tradisi pesantren juga dikembangkan sebagai wahana pendidikan kepemimpinan umat dan pengembangan kecakapan berbahasa Arab dan Inggris. Dengan demikian, model pengorganisasian kurikulum UIN Maliki Malang menggunakan correlated curriculum. Wa al-Läh a lam bi al-sawāb.

\section{Daftar Pustaka}

Anshari, Endang Saifuddin. 1987. Ilmu, Filsafat dan Agama. Surabaya: Bina Ilmu.

Azra, Azyumardi. 1999. Pendidikan Islam Tradisi dan Modernisasi Menuju Milenium Baru. Jakarta: Logos Wacana Ilmu.

Bakar, Oesman. 2008. Taubid dan Sains Perspektif Islam tentang Agama dan Sains, ter. Yuliani Liputo dan M.S. Nasrulloh. Bandung: Pustaka Hidayah.

Bilgrami, Hamid Hasan dan Sayid Ali Asyraf. 1999. Konsep Universitas Islam, ter. Machnun Husein. Yogyakarta: Tiara Wacana.

Furchan, A. dkk. 2005. Pengembangan Kurikulum Berbasis Kompetensi di PTAI. Yogyakarta: Pustaka Pelajar.

Gorton, 1976. School Administration Challenge and Opportunity for Leadership. New York: Brown Company Publishers.

Hamdi, Zainul. 2005. "Menilai Ulang Gagasan Integrasi Ilmu Pengetahuan sebagai Blue Print Pengembangan Keilmuan UIN", dalam Zainal Abidin Bagir, dkk (ed.), Integrasi Ilmu dan Agama Interpretasi dan Aksi. Yogyakarta: MYIA-CRCS dan Suka Press.

Ma'arif, Syafi'i. 1993. Peta Bumi Intelektualisme Islam di Indonesia. Bandung: Mizan.

Mastuhu. 1994. Dinamika Sistem Pendidikan Pesantren. Jakarta: INIS. 
Muhaimin. 2003. Wacana Pengembangan Pendidikan Islam. Yogayakarta: Pustaka Pelajar.

Pedoman Pendidikan Universitas Islam Negeri (UIN) Malang Tahun Akademik 2011/2012.

Saefuddin, A.M, et.al. 1998. Desekularisasi Pemikiran: Landasan Islamisasi. Bandung: Mizan.

Suprayogo, Imam. 2007. Hubungan antara Perguruan Tinggi dan Pesantren. Malang: UIN Malang Press.

Tafsir, Ahmad. 2010. Filsafat Pendidikan Islam Integrasi Jasmani, Rohani, dan Kalbu Memanusiakan Manusia. Bandung: Remaja Rosdakarya.

Zainuddin, M. dkk. (ed.). 2009. Memadu Sains dan Agama. Malang: UIN Press. 